\title{
THE EFFECTS OF THE URUGUAY ROUND: EMPIRICAL EVIDENCE FROM U.S. INDUSTRY
}

\author{
JOHN MUTTI, RACHELLE SAMPSON, and BERNARD YEUNG*
}

\begin{abstract}
This article uses an event study to evaluate the anticipated results of the Uruguay Round on U.S. industry. Economists commonly use computable general equilibrium $(C G E)$ models to predict the net economic efficiency effects of trade agreements. The event study method represents a complementary approach that relies on stock price movements to assess how investors predict that an event, in this case the conclusion of the Uruguay Round, will affect industry profitability. The empirical estimates indicate that U.S. industries with comparative advantage (disadvantage) experience positive (negative) stock price reactions, reflecting an increase (a decrease) in the industry trade and investment opportunities as well as an increased (decreased) return to existing tangible and intangible assets. For the market as a whole, the variation in stock prices does not differ significantly from zero, and the economic magnitude of industry gains and losses is small. These results are consistent with most CGE assessments and with the skeptical attitude that the real impact of the Uruguay Round Agreement remains uncertain. (JEL F13, F2)
\end{abstract}

\section{INTRODUCTION}

The Uruguay Round of trade negotiations that concluded in December 1993 represents the eighth round of multilateral trade negotiations that has occurred over the past 50 years. The breadth of consensus reached by over 150 nations was previously thought unattainable. The Uruguay Round of the General Agreement on Tariffs and Trade (GATT) covers a much wider range of transactions than was the case in prior agreements. In addition to reducing tariffs, the Uruguay Round disciplines many nontariff barriers. Additionally, trade in intellectual property and in services is now governed by GATT principles. Other major developments

*This is a revised version of a paper presented at the 73rd annual Western Economic Association Conference, Lake Tahoe, Nevada, June 29, 1998, at a session organized by Jeffrey Nugent, University of Southern California. The authors acknowledge helpful comments by three anonymous referees and by session participants. Sampson and Yeung received research support from the University of Michigan Business School's Center for International Business Education.

Mutti: Meyer Professor, Economics, Grinnell College, Phone 515-269-3143, Fax 515-269-4985, E-mail mutti@grinnell.edu

Sampson: Assistant Professor, International Business, New York University, Phone 212-998-0975, Fax 212995-4221, E-mail rsampson@stern.nyu.edu

Yeung: Krasnoff Professor, International Business, New York University, Phone 212-998-0425, and University of Michigan, Fax 734-936-8715, E-mail byeung@umich.edu include the establishment of the World Trade Organization (WTO), a body that will monitor compliance with the agreement, administer a stronger dispute resolution mechanism to settle trade-related disputes, and provide a forum for future multilateral negotiations.

What will be the impact of this ambitious trade liberalization agreement? Proponents claim that it will generate hundreds of billions of dollars of additional income annually. Some industry leaders, however, argue that the Uruguay Round Agreement will result in a flood of imports that will seriously injure U.S. industry, displace thousands of workers, and bankrupt many companies. Many economists suggest the effects are likely to be quite small [see Schott (1994) for a survey of early work, and Martin and Winters (1996) for projections based on actual offers made]. Deardorff (1994) states, "The Round itself, at least in terms of its economic effects, may not make a big difference" (p. 7). The computable general equilibrium (CGE) analysis of Harrison et al.

\section{ABBREVIATIONS}

CGE: computable general equilibrium

GATT: General Agreement on Tariffs and Trade WTO: World Trade Organization 
(1997) projects that the U.S. annual gain in income will be $\$ 13$ billion or $0.3 \%$ of GDP.

This article investigates how investors assess the result of the Uruguay Round Agreement. Specifically, it examines how U.S. stock prices in 198 different three-digit SIC industries reacted to news of the successful conclusion of the Uruguay Round. It finds stock price reactions are positive for U.S. industries that are net exporters or technology intensive, that is, characteristics of industries with a comparative advantage internationally. Overall, the net change in U.S. capital value is insignificantly negative and the magnitude of the capital value created and destroyed by the Uruguay Round is rather small. These results are broadly consistent with projections based on CGE models and also with the attitude that the impact of the Uruguay Round Agreement remains uncertain, depending on its actual implementation.

The remainder of this article is organized as follows. Section II briefly summarizes the major agreements reached in the Uruguay Round negotiations and previous economic assessments of their importance. It also explains how an event study of the U.S. stock market's reaction to the Uruguay Round provides another estimate of its effect. Section III covers the data and methodology used. Results follow in Section IV. The article concludes with a brief discussion of the results and their implications.

\section{THE URUGUAY ROUND AND} ALTERNATIVE MEANS OF ASSESSMENT

Table 1 summarizes the key results of the Uruguay Round that are likely to affect U.S. industries. These provisions are discussed extensively by Schott (1994). As a simple overview, U.S. export industries are likely to benefit from foreign liberalization, while import-competing industries, especially textiles and apparel, are likely to face greater competition. Agreement in new areas such as services, intellectual property, and traderelated investment suggests that additional benefits will eventually be realized as these provisions are phased in and ongoing negotiations completed. The stronger administrative framework of the WTO, its dispute resolution mechanism, and its trade policy review procedure all promise more effective imple- mentation of the agreements reached than was possible under the GATT. Nevertheless, many of the most sensitive items are phased in extremely slowly, and opponents may devise new protectionist policies to offset even those concessions.

The CGE studies cited above generally analyze tariff reductions for manufactured goods, the conversion of agricultural import barriers to tariffs and the reduction of agricultural subsidies, and the elimination of the MultiFibre Agreement and voluntary export restraints. Does including new areas such as intellectual property result in larger projected gains? Attempts to measure the consequences of other aspects of the agreement are extremely sensitive to the market structure assumed and the response of producers in other countries (Maskus and Konan, 1994). The general equilibrium effects further depend on the assumed adjustment costs, savings rates, and economic impact of foreign direct investment. Formal models of the Uruguay Round's effects appear to leave broad areas of uncertainty over its eventual impact.

The stock market's assessment of the effects of the Uruguay Round Agreement has not yet been explored. By measuring the change in firm value as a result of the Uruguay Round, this article provides insights complementary to those obtained from the CGE approach. The value of any firm on the stock market is based on the present value of net cash flows generated by that firm's tangible and intangible assets. Firm value also includes an investment option component that measures the value of future or potential investment by the firm (Ingersoll and Ross, 1992). Thus, firm value will vary according to the expected change in net cash flow and investment opportunities caused by the Uruguay Round Agreement.

The use of stock prices to study international trade issues is gradually becoming more common (e.g., Grossman and Levinsohn, 1989; Hartigan et al., 1986; Brander, 1991; and Lenway et al., 1996). Thompson (1993, 1994) applies the event study methodology to investigate the impact of the 1987 U.S.-Canada Free Trade Agreement on Canadian firms and industries. She finds that firm-level stock price reactions to the agreement are positively related to natural resource intensity and negatively related to 
TABLE 1

Key Results of the Uruguay Round

\begin{tabular}{|c|c|}
\hline Area & New Provision \\
\hline \multicolumn{2}{|l|}{ General measures } \\
\hline \multirow[t]{2}{*}{ General tariffs } & Average tariffs on industrial goods to be reduced from $6.4 \%$ to $4 \%$ \\
\hline & $\begin{array}{l}\text { Tariffs to be eliminated in some sectors (including agricultural, medical, and } \\
\text { construction equipment and pharmaceuticals) }\end{array}$ \\
\hline \multirow[t]{3}{*}{ Subsidies } & Clearer categorization of actionable and nonactionable subsidies \\
\hline & Prohibition of subsidies linked to export performance or local content requirements \\
\hline & Subsidies for research or to help regionally disadvantaged areas allowed \\
\hline Safeguards & $\begin{array}{l}\text { Tariffs or quotas are allowed to be used where a particular product is being } \\
\text { imported in quantities sufficient to cause serious injury to the domestic industry- } \\
\text { maximum of } 8 \text { years of protection, Voluntary Export Restraints (VERs) banned }\end{array}$ \\
\hline \multirow[t]{2}{*}{$\begin{array}{l}\text { "Standard" based rules } \\
\text { of trade }\end{array}$} & $\begin{array}{l}\text { Guidelines established for the use of product standards applied to imports (i.e., that } \\
\text { are not more restrictive than necessary to fulfill a legitimate objective) }\end{array}$ \\
\hline & $\begin{array}{l}\text { Guidelines are set out to regulate the measures that may be taken by a nation to } \\
\text { preserve human, plant, and animal health }\end{array}$ \\
\hline Investment rules & $\begin{array}{l}\text { Local content requirements, trade balancing requirements (i.e., imports in certain } \\
\text { proportion to exports), and foreign exchange balancing requirements prohibited }\end{array}$ \\
\hline \multirow[t]{3}{*}{$\begin{array}{l}\text { Dispute settlement } \\
\text { procedures }\end{array}$} & $\begin{array}{l}\text { Panel reports are automatically adopted by the WTO, failing a "reverse" consensus, } \\
\text { also strict time schedule set for steps in resolution process }\end{array}$ \\
\hline & Retaliatory action may be sanctioned by the WTO \\
\hline & Appellate review of panel reports now available \\
\hline Creation of the WTO & $\begin{array}{l}\text { The WTO, an organization representing the signatories to the GATT, is created to } \\
\text { monitor compliance with the agreement and to promote further negotiations }\end{array}$ \\
\hline \multicolumn{2}{|l|}{ Specific measures } \\
\hline \multirow[t]{4}{*}{ Agriculture } & Export subsidies to be reduced by $36 \%$ in value over 6 years \\
\hline & Volume of subsidized exports to be reduced by $21 \%$ over 6 years \\
\hline & Quotas to be converted to tariffs and then cut by $36 \%$ by the year 2000 \\
\hline & Domestic farm subsidies to be cut by $20 \%$ over 6 years \\
\hline \multirow[t]{2}{*}{ Textiles and clothing } & $\begin{array}{l}\text { Requires the phase out of the Multifibre Agreement-all trade in textiles and } \\
\text { clothing to be brought within the GATT - reductions in tariffs and increases in } \\
\text { products covered by the GATT gradually over the } 10 \text { year phase in period }\end{array}$ \\
\hline & $\begin{array}{l}\text { Tariff bindings made on many products within these industries (U.S. reduction in } \\
\text { tariffs in this industry will be approximately } 12 \% \text { overall) }\end{array}$ \\
\hline \multirow[t]{2}{*}{ Services } & $\begin{array}{l}\text { Requires most favored nation treatment, national treatment, and the free flow of } \\
\text { payments and transfers for trade in services }\end{array}$ \\
\hline & $\begin{array}{l}\text { Commitments by some members of the WTO to make investment review regimes } \\
\text { more transparent }\end{array}$ \\
\hline Intellectual property & $\begin{array}{l}\text { Establishes minimum standards for protection of intellectual property and for their } \\
\text { enforcement (this standard is higher than any previously required under } \\
\text { international law, but lower than that existing in the U.S.) }\end{array}$ \\
\hline
\end{tabular}

plant scale disadvantage. At the industry level and for the market as a whole, the Canadian stock price reactions are insignificant.

This article analyzes the U.S. industry response to the Uruguay Round Agreement. Stock market data for other developed countries would likely generate interesting results, too, because they tend to depend more on trade than does the U.S. economy. The ability of developing economies' stock data to generate meaningful results may be a bit more doubtful, however. The reason is that stock prices in these markets seem to have less information content with respect to the different prospects of individual firms and are more prone to random noise affecting all stocks in a similar way (Morck et al., 1998).

This article examines the overall market reaction but especially the relationship between an individual industry's stock price reaction and the industry's characteristics. The stock price reaction, as used in this article, is the cumulative abnormal return on the stock. An industry's rate of return is 
determined by the size-weighted average rate of return of all firms in the industry. The abnormal return is calculated as the difference between an industry's rate of return and the market return. That difference is summed over the trading days surrounding the announcement of the successful conclusion of the Uruguay Round negotiations.

Traditional trade theory (Mussa, 1974) suggests that the change in cash flow should be in the same direction as the change in output price. Because trade and investment liberalization can be expected to decrease the price of import-competing goods relative to exported goods, the cash flow will rise for U.S. export industries and decline for import-competing industries. In addition, the value of potential investment opportunities grows in exporting industries and shrinks in import-competing industries. Finally, trade and investment liberalization should decrease the risk premium, which is relevant in establishing the appropriate rate by which to discount future cash flows, for industries that benefit from greater and hence more diversified market access (export sectors); similarly, it will increase the premium for industries that will be adversely affected by greater market access (import-competing sectors).

U.S. trade barriers tend to be greater in industries with low wages, a higher proportion of unskilled workers, and a high labor/output ratio (Baldwin, 1985, p. 165). These also are industries in which the United States has a comparative disadvantage, as suggested by the Heckscher-Ohlin factor endowments theory of trade: a country will import goods that use relatively scarce factors intensively, and export goods that use relatively abundant factors intensively. If foreign countries have imposed trade barriers to protect industries using their relatively scarce factors, U.S. industries with comparative advantage, such as those that use skilled labor and intangible capital intensively (Baldwin, 1971; Deardorff, 1984), will gain from multilateral trade liberalization.

A more direct indication of comparative advantage is the net export position of an industry, a measure also used in the empirical analysis. If the success of U.S. export industries has led foreign governments to raise trade barriers against them, then industries with those characteristics stand to gain from trade liberalization. In addition, these characteristics are useful in identifying U.S. industries that have special expertise and technical knowledge that they may not exploit through international trade in goods. These industries are likely to benefit from many of the rule-based agreements in services, intellectual property, and direct investment. Of course, the benefits are more certain and immediate for some industries, while for others they may be delayed considerably, depending on the implementation of the Uruguay Round Agreement.

\section{DATA AND METHODOLOGY}

Selection of an appropriate date is critical to an event study. Several possible dates appear relevant to the completion and ratification of the Uruguay Round, as suggested by Preeg's (1995) narrative of the negotiations and by the Congressional Quarterly Almanac (1994) discussion of legislative votes. Those dates are summarized in Table 2. Applying the preferred empirical specification reported in Section IV to each of these event days yields significant and robust results only for December 15, 1993. On that day, the Uruguay Round Agreement was signed just before midnight in Marrakech, Morocco, about 6:00 p.m. EST in the United States. Prior to that day investors apparently were uncertain whether agreement would be reached by the time President Bill Clinton's fast track authority expired on December 15, 1993. If consensus were not reached, the President would have to seek an extension of that authority from the U.S. Congress, a step that would provide opponents another opportunity to weaken the agreement. Therefore, it is not surprising that the announcement of the successful conclusion of the Uruguay Round on the evening of December 15th, 1993, had news content. ${ }^{1}$

1. With respect to other possible dates, two especially merit further comment. On December 3, 1993, negotiators reached an agreement in agriculture. Because talks had broken down in December 1990 over U.S.-E.U. agricultural disagreements, achieving a compromise in this area did increase the likelihood of a unified Uruguay Round Agreement being reached. The stock price reactions on this day were stronger than reactions to other nonevents, but still not significant. On November 29, 1994, the House ratified the implementation bill, and on December 1, 1994, the Senate ratified the bill. The House vote to approve was 288 to 146 , and the Senate vote was 76 to 24 , both indications of bipartisan support that was lacking in the NAFTA vote a year earlier. 
TABLE 2

Chronology of Events

\begin{tabular}{ll}
\hline Date & \multicolumn{1}{c}{ Event } \\
\hline February 28, 1993 & U.S. fast track authority expires: renewed with deadline of December 15, 1993 \\
November 17, 1993 & NAFTA passes U.S. Congress \\
December 3, 1993 & Negotiators reach agreement covering agricultural trade \\
December 15, 1993 & Uruguay Round concludes; President Clinton's fast track authority expires \\
April 15, 1994 & U.S. formally signs the Uruguay Round Agreement \\
September 12, 1994 & Bill implementing the Uruguay Round is informally introduced in the U.S. Senate \\
September 27, 1994 & Bill is formally introduced into Congress for debate \\
November 23, 1994 & The Republican Senate Leader Bob Dole expresses his support for WTO \\
November 29, 1994 & The U.S. House of Representatives passes a bill ratifying U.S. participation in the WTO \\
December 1, 1994 & The U.S. Senate passes a bill ratifying U.S. participation in the WTO \\
January 1, 1995 & The WTO formally comes into existence
\end{tabular}

How can the stock market response to that information be measured and related to industry characteristics? A three-day event window is employed in the analysis below $\left(t_{-1}, t_{0}, t_{+1}\right)$. December 15,1993 is the event day, $t_{0}$, assumed in the results reported, but repeating the analysis using December 16, 1993, as the event day gives qualitatively similar results.

The empirical specification is as follows: ${ }^{2}$

$$
\mathrm{CAR}_{i}=\beta \mathbf{X}_{i},
$$

where $\mathrm{CAR}_{i}$ is the cumulative abnormal return for industry $i$ as suggested by Brown and Warner (1980) and calculated from the Center for Research in Security Prices (CRSP) daily cum dividend series. It is defined as

$\mathrm{CAR}_{i}$

$$
=\sum_{t=-1}^{+1}\left[\left(\sum_{j}\left(R_{i j t} \times \frac{V_{i j t}}{\sum_{j} V_{i j t}}\right)\right)-\mathrm{MR}_{t}\right],
$$

where the variable $t$ is the day, where the event date occurs at $t=0 ; j$ is the firm within industry $i ; R_{i j t}$ is the return for firm $j$ in industry $i$ for day $t ; V_{i j t}$ is the value of firm $j$ in industry $i$ on day $t$ (value $=$ number of shares outstanding $\times$ share price); and

2. Note that the intercept has been suppressed as the null hypothesis is that the cumulative abnormal return before and after the conclusion of the Uruguay Round is zero. Inclusion of an intercept does not improve the explanatory power of the regression equation, and the intercept coefficient is in all cases insignificant.
$\mathrm{MR}_{t}$ is the value-weighted market return. $\mathbf{X}_{i}$ is a vector of independent variables that represent industry characteristics.

Proxies that reflect an industry's potential comparative advantage are as follows: CAPITAL $_{i}$ is the difference between the ratio of net property, plant, and equipment (tangible capital) per employee for industry $i$ and the corresponding U.S. economywide ratio, defined as

CAPITAL $_{i}$

$$
\begin{aligned}
= & \left(\frac{\mathrm{EQUIPMENT}_{i}}{\mathrm{LABOR}_{i}}\right) \\
& -\left(\frac{\sum_{i} \mathrm{EQUIPMENT}_{i}}{\sum_{i} \mathrm{LABOR}_{i}}\right) ;
\end{aligned}
$$

TECHNOLOGY ${ }_{i}$ is the difference between the research and development spending per employee for industry $i$ and the corresponding U.S. economywide ratio, defined as

\section{(1c)}

\section{TECHNOLOGY}

$$
=\left(\frac{\mathrm{R}_{i} \& \mathrm{D}_{i}}{\mathrm{LABOR}_{i}}\right)-\left(\frac{\sum_{i} \mathrm{R}_{i} \& \mathrm{D}_{i}}{\sum_{i} \mathrm{LABOR}_{i}}\right) ;
$$

NEXPORTS $_{i}$ is (exports - imports)/total shipment in industry $i$; and $\mathrm{HCAPITAL}_{i}$ is a proxy for human capital, represented as (total payroll - wages to production workers)/ value added (denoted HCAPITAL1) and also as (total compensation - number of employees times the minimum wage)/value added 
(denoted HCAPITAL2). The measure for industry $i$ is expressed relative to the economywide average. ${ }^{3}$

The sample consists of U.S. industries at the three-digit Standard Industrial Classification (SIC) level of aggregation. This level of aggregation provides a sizable number of industry observations and sufficient degrees of freedom for econometric analysis. Further, it allows industry characteristics to be identified that apply to most subindustries included in each industry sector. In contrast, the one- and two-digit SIC levels of aggregation combine many activities that are quite dissimilar. The three-digit level of aggregation also avoids an overly detailed industry classification. Because firms often produce products categorized in more than one fourdigit industry, misclassification of firm data is less likely at the three-digit level than at the four-digit level.

Various industries are specifically excluded from the analysis. The sample omits nontradable industries such as real estate, automotive service stations, personal services, and utilities. These exclusions are made on the grounds that any impact of the Uruguay Round Agreement on such nontradable service industries is quite uncertain. To mitigate the introduction of erroneous but sizable noise, the sample also excludes firms that are not traded continuously over the event window. Such firms include those listed for the first time, or delisted, or suspended from trading during the event window. Finally, the sample excludes foreign firms listed in U.S. stock markets, because a greater portion of these companies' assets are more likely to be located outside of the United States when compared to U.S. firms. Based on these criteria, there are 202 industries available.

Data for the construction of CAPITAL and TECHNOLOGY are obtained from the Compustat annual tapes by the following procedure: sort firms into three-digit classifications according to their declared core

3. NEXPORTS is calculated from table 28 in "Foreign and Domestic Exports, F.A.S.; General Imports, Customs," National Trade Data Bank, U.S. Census Bureau, Department of Commerce, 1994; and from table 1 in "Value of Product Shipments," 1994 Annual Survey of Manufactures, U.S. Census Bureau, Department of Commerce. HCAPITAL is calculated from tables 2 and 3 in "Statistics for Industry Groups and Industries," 1994 Annual Survey of Manufactures. industry, aggregate firm data into industry data, form appropriate ratios from the industry data, and compare those ratios to the U.S. economywide ratios calculated from the Compustat data set. Because the Compustat tapes do not contain enough firm-level data to define factor intensities on the basis of value-added shares, the denominator of the CAPITAL and TECHNOLOGY variables is the number of employees. We expect these independent variables, as well as HCAPITAL and NEXPORTS, to be positively correlated with the stock price reaction to the conclusion of the Uruguay Round.

Annual, firm-level data for 1993 are selected because that year is the closest one before and including the conclusion of the Uruguay Round. Inclusion of the event date in this period is unlikely to create misleading results, because the event date is near the financial year end for most firms. Besides, the reallocation of real resources such as physical assets and employment due to the Uruguay Round would not likely occur until after the agreement was ratified by U.S. Congress in late 1994.

\section{EMPIRICAL RESULTS}

\section{A. Basic Findings}

Table 3 shows the market return and the cumulative market return from December 14 to December 20, 1993. Market returns were positive on both December 15 and 16 and negative for all other trading days. Based on market performance for the previous 245 days, returns on each of the days shown are insignificantly different from the average. None of the cumulative market returns is significant. Overall, the single-day and the cumulative market returns indicate that, while the stock market did react positively, investors did not expect the Uruguay Round Agreement to have a substantial net impact on the value of U.S. publicly traded firms. A review of the Wall Street Journal News index suggests that there were no other major newsworthy events around this window that would influence the pattern observed.

Tables 4 and 5 show summary statistics of the variables described in Section III. Univariate statistics are displayed in Table 4 and simple correlation coefficients are displayed in Table 5. The mean cumulative abnormal 
TABLE 3

Market Return

\begin{tabular}{|c|c|c|c|c|}
\hline Day & $\begin{array}{l}\text { Market } \\
\text { Return }^{\mathrm{a}}\end{array}$ & t-Ratio ${ }^{b}$ & $\begin{array}{c}\text { Cumulative } \\
\text { Market Return }\end{array}$ & t-Ratio $^{b}$ \\
\hline$t_{-1}:$ December 14, 1993 & -0.001981 & -0.39069 & -0.001981 & -0.39069 \\
\hline$t_{0}:$ December 15, 1993 & 0.002368 & 0.46702 & 0.000387 & 0.53969 \\
\hline$t_{+1}:$ December 16, 1993 & 0.006325 & 1.24741 & 0.006712 & 0.76426 \\
\hline$t_{+2}:$ December 17, 1993 & -0.000610 & -0.12030 & 0.006102 & 0.60172 \\
\hline$t_{+3}:$ December $20,1993^{\mathrm{c}}$ & -0.002429 & -0.47905 & 0.003673 & 0.32396 \\
\hline
\end{tabular}

${ }^{a}$ Market return is the value-weighted return, cum dividends, of all listed stocks.

${ }^{\mathrm{b}}$ The standard deviation for the purposes of calculating the t-ratio was computed from a sample of 245 trading days prior to the event window, as suggested by Brown and Warner (1985).

${ }^{\mathrm{c}}$ December 18, 1993, was a Saturday and December 19 was a Sunday; hence they were not trading days.

TABLE 4

Event Window, December 14-16, 1993: Summary Statistics

\begin{tabular}{lccccc}
\hline & Mean & Median & $\begin{array}{c}\text { Standard } \\
\text { Deviation }\end{array}$ & Maximum & Minimum \\
\hline CAR & -0.0021 & -0.0006 & 0.0244 & 0.0634 & -0.1167 \\
CAPITAL & -3606 & -42993 & 103299 & 435759 & -82552 \\
TECHNOLOGY & -3085 & -5164 & 5187 & 36936 & -5825 \\
NEXPORTS & -0.1904 & -0.0100 & 0.5802 & 0.3500 & -4.1100 \\
HCAPITAL1 & 0 & -0.0066 & 0.0521 & 0.1534 & -0.1166 \\
HCAPITAL2 & 0 & 0.0005 & 0.0941 & 0.2105 & -0.2495 \\
\hline
\end{tabular}

TABLE 5

Event Window, December 14-16, 1993: Simple Correlation Coefficients

\begin{tabular}{|c|c|c|c|c|c|}
\hline & CAR & CAPITAL & TECHNOL & NEXPORTS & HCAPITAL1 \\
\hline CAPITAL & $\begin{array}{c}-0.0619 \\
(0.3864) \\
(198)\end{array}$ & & & & \\
\hline TECHNOLOGY & $\begin{array}{c}0.2087 \\
(0.0032) \\
(198)\end{array}$ & $\begin{array}{c}-0.0050 \\
(0.9440) \\
(198)\end{array}$ & & & \\
\hline NEXPORTS & $\begin{array}{c}0.3902 \\
(0.0001) \\
(126)\end{array}$ & $\begin{array}{c}0.1608 \\
(0.0721) \\
(126)\end{array}$ & $\begin{array}{c}0.1030 \\
(0.2511) \\
(126)\end{array}$ & & \\
\hline HCAPITAL1 & $\begin{array}{c}0.0886 \\
(0.3161) \\
(130)\end{array}$ & $\begin{array}{c}-0.1559 \\
(0.0766) \\
(130)\end{array}$ & $\begin{array}{c}0.2364 \\
(0.0068) \\
(130)\end{array}$ & $\begin{array}{c}-0.0285 \\
(0.7416) \\
(136)\end{array}$ & \\
\hline HCAPITAL2 & $\begin{array}{c}0.1054 \\
(0.2326) \\
(130)\end{array}$ & $\begin{array}{c}-0.0027 \\
(0.9761) \\
(130)\end{array}$ & $\begin{array}{c}-0.0382 \\
(0.6658) \\
(130)\end{array}$ & $\begin{array}{c}0.1226 \\
(0.1552) \\
(136)\end{array}$ & $\begin{array}{c}0.5468 \\
(0.0001) \\
(140)\end{array}$ \\
\hline
\end{tabular}

Note: The numbers in the first set of parentheses below sample coefficients are estimated probability levels for the hypothesis that the true correlation is zero. The numbers in the second set are number of industries without missing observations. 
return for the three-day window (December 14-16) for the 198 industry sample is $-0.21 \%$. This value is not significantly different from zero, with a t-ratio of 0.086 . CAPITAL is in dollars of property, plant, and equipment per employee and TECHNOLOGY is measured in dollars of R\&D spending per employee, both expressed relative to the appropriate economywide average. Mean values for CAPITAL and TECHNOLOGY are less than zero. Among the included industries are some that are large and highly capital and technology intensive, which results in the weighted average capital intensity exceeding the simple average. The means of both CAPITAL and TECHNOLOGY are not significantly different from zero, with t-ratios of 0.035 and 0.595 , respectively. The average of NEXPORTS is negative, not a surprising result given the overall trade deficit in 1993.

As shown in Table 5, the abnormal return, CAR, is positively and significantly correlated with technology intensity (TECHNOLOGY) and net export intensity (NEXPORTS) beyond the $1 \%$ level. The strong correlation indicates that industries with above (below) average technological intensity and net export (import) industries did experience appreciation (depreciation) in firm value during the event window. However, CAR is insignificantly related to capital intensity (CAPITAL) and human capital intensity (HCAPITAL1 and HCAPITAL2). Indeed, the correlation between CAPITAL and CAR is even negative. The physical capital and human capital intensity variables may be measured less accurately or may simply be less successful proxies in identifying U.S. industries that have a comparative advantage and/or will benefit from reductions in foreign trade barriers.

The relatively stronger results on technology-intensive industries may indicate that current trade barriers are higher on products in these industries than in purely capital-intensive industries. It is also possible that the minimum standards of intellectual property protection provided via the Uruguay Round Agreement enhances the value of industries that rely on intellectual property protection to appropriate rents. Industries investing substantial resources into $R \& D$ are the largest users of traditional forms of intellectual property protection, such as patents. As the value of patents increases from enhanced international intellectual property rights protection, the value of the patenting firm increases accordingly. Thus, investors appear optimistic over the intellectual property protection that will in fact be provided.

Notice that the four intensity variables do not show a consistent pattern of correlation. For example, net export intensity is not significantly correlated with any of the other intensity variables. While the two human capital intensity measures are highly correlated, they similarly do not show any consistent and significant correlation with other intensity variables. The lack of consistent correlation among these proxies for comparative advantage supports the use of multiple proxies to capture the characteristics of industries that may benefit from the Uruguay Round Agreement.

Table 6 displays ordinary least squares regression results explaining the relationship between cumulative abnormal return and variables representing comparative advantage. In columns (1)-(5), each explanatory variable enters independently. In columns (6) and (7) all intensity measures enter simultaneously, using the two human capital intensity measures alternately. All regressions use White's (1980) heteroskedastic consistent standard error to calculate the t-statistics whenever White's $\chi^{2}$ test indicates the presence of heteroskedasticity.

The simple regression results reported in Table 6 duplicate the correlations reported in Table 5. Both NEXPORTS and TECHNOLOGY are highly positive and significant beyond the 0.01 level. The multiple regression results suggest that in the presence of net export intensity the technology-intensity measure loses its explanatory power. Perhaps this outcome can be explained as follows. While the U.S. comparative advantage is likely in technology-intensive industries, there are other determinants of U.S. comparative advantage not captured by technology intensity. We check this interpretation by replacing the net trade variable with a less informative variable. Recall that NEXPORTS is defined as (exports imports)/total shipment. A less informative measure is a dummy that is equal to one when NEXPORTS is positive, and zero otherwise. When this less informative trade variable is used instead of the original 
TABLE 6

Event Window, December 14-16, 1993: Results from Regressing Cumulative Abnormal Return on Measures of Comparative Advantate

\begin{tabular}{|c|c|c|c|c|c|c|c|}
\hline $\begin{array}{l}\text { Independent } \\
\text { Variable }\end{array}$ & (1) & (2) & (3) & (4) & (5) & (6) & (7) \\
\hline CAPITAL & $\begin{array}{c}-1.3928 \mathrm{E}-8 \\
(2 \mathrm{E}-8)\end{array}$ & & & & & $\begin{array}{c}-1.0455 \mathrm{E}-8 \\
(2 \mathrm{E}-8)\end{array}$ & $\begin{array}{c}-1.4714 \mathrm{E}-8 \\
(2 \mathrm{E}-8)\end{array}$ \\
\hline TECHNOLOGY & & $\begin{array}{c}90 \mathrm{E}-8^{* * * *} \\
(28 \mathrm{E}-8)\end{array}$ & & & & $\begin{array}{c}8.0852 \mathrm{E}-8 \\
(34 \mathrm{E}-8)\end{array}$ & $\begin{array}{l}18.8 \mathrm{E}-8 \\
(33 \mathrm{E}-8)\end{array}$ \\
\hline NEXPORTS & & & $\begin{array}{c}0.0132^{* * * *} \\
(0.0027)\end{array}$ & & & $\begin{array}{c}0.0135^{* * *} \\
(0.0029)\end{array}$ & $\begin{array}{c}0.0130^{* * *} \\
(0.0130)\end{array}$ \\
\hline HCAPITAL1 & & & & $\begin{array}{c}0.0328 \\
(0.0246)^{\mathrm{a}}\end{array}$ & & $\begin{array}{c}0.0357 \\
(0.0325)\end{array}$ & \\
\hline HCAPITAL2 & & & & & $\begin{array}{c}0.0219 \\
(0.0187)\end{array}$ & & $\begin{array}{c}0.0142 \\
(0.0177)\end{array}$ \\
\hline $\mathrm{R}^{2}$ & 0.0034 & 0.0491 & 0.1554 & 0.0075 & 0.0105 & 0.1681 & 0.1643 \\
\hline Sample Size & 198 & 198 & 126 & 130 & 130 & 126 & 126 \\
\hline
\end{tabular}

Note: Standard errors appear in parentheses below parameter estimates.

${ }^{a}$ White's heteroskedastic consistent errors used where the null hypothesis of homoskedastic variance is rejected. $* * * p<0.01$.

NEXPORTS variable, TECHNOLOGY regains its significance and the probability value of the less informative trade variable is $11 \%$.

Another reason for the difference between the results in column (2) and column (6) or (7), however, is the difference between the two samples used in the estimation. For 72 industries, the technology-intensity measure is available but not the net export measure. Repeating the regression in column (2) using the sample that excludes these 72 industries also results in TECHNOLOGY losing its explanatory power. Are there any systematic differences between the technology intensity of the full sample and of the 72 industries for which the net export variable is not available? The mean technology-intensity value for the excluded industries is less than for the full sample, although the difference is not statistically significant. The median value of the excluded industries is smaller than the median of the full sample, and based on nonparametric test statistics this difference is statistically significant. The median R\&D-intensity value of the excluded industries is -5825 , which is lower than the full sample median with a probability value of 0.0032 based on a median two-sample test and a probability value of 0.0007 based on the Wilcoxon rank sum test.

While most of the excluded industries are not very $\mathrm{R} \& \mathrm{D}$ intensive, visual inspection nevertheless shows that some of those excluded are highly $R \& D$ intensive. Both groups of observations may have an important influence on the estimated outcome. One way to assess the importance of such groupings, which differs from the observation-by-observation treatment applied in residual diagnostic tests, is to drop from the full sample the top 5\% and the bottom 5\% of observations ordered by R\&D intensity. Using that sample results in the TECHNOLOGY coefficient from the simple regression becoming insignificant, an indication that the influence of technology apparently is not a continuous linear relationship but rather more important when values diverge substantially from the mean.

\section{B. Robustness}

In obtaining the results reported in Tables 4-6 we checked for the presence of outliers. In the original sample, there were four industries with residuals three times greater than the standard error: forest products, metal mining services, nonmetallic mineral services, and bus charter services. Including these outliers causes capital intensity to become positive and significant but technology intensity to become insignificant. These are the only industries selected from the Compustat file where a single firm accounts for the 
entire industry. To avoid having the results affected by noise, which will be more likely in single-firm industries, we dropped these four observations from the sample represented in Tables 4-6.

A further question to address is whether the observed stock price reaction is permanent or transitory. The market may first react positively to the announcement of the Uruguay Round Agreement and then reverse its assessment completely as it learns more about the agreement. It is futile to use an event study method to gauge how the market assesses an event over a long window, however, because other events dilute the impact of the focal event. We resorted to the following compromise. Moving the event window one day forward to December 15-17, and also expanding the event window to December 14-17, yields results substantially similar to those reported in Table 6, with slightly lower significance. Moving to a postevent window, December 17, 20, and 21, 1993 (December 18 and 19 were not trading days), yields no significant results. All the regression coefficients that were significant (i.e., technology intensity and net export intensity) now have a sign opposite to but a magnitude substantially smaller than those reported in Table 6 .

Missing variables may cause potentially spurious results. Based on White's $\chi^{2}$ test, heteroskedasticity generally is not a problem. Because heteroskedasticity often is a sign of a missing variable, that possibility is less of a concern.

The possibility that a handful of industries with large NEXPORTS, TECHNOLOGY, and abnormal returns may explain the significance of the results in Tables 4-6 raises concerns over their generality. To purge the influence of observations with large magnitudes and to confine attention only to the independent variables' influence on the sign of the stock price reactions (CAR $>0$ or CAR $<0$ ), Equation (1a) is estimated using a logit specification. This specification is run over four event windows: (1) December 14-16, (2) December 15-17, (3) December 14-17, and (4) December 17, 20, and 21. Results are substantially similar, in terms of the sign of each coefficient and its significance, to those reported in Tables 4-6.

On the basis of the above robustness checks, we infer that the investment commu- nity may have slightly revised its assessment of the Uruguay Round Agreement on learning more about the terms of the agreement. Despite this readjustment, investors still expected the Uruguay Round to have a positive (negative) effect on industries with comparative advantage (disadvantage) as captured by relative technology intensity and net export intensity.

\section{Economic Significance}

To what extent did the stock market revalue industries in response to the Uruguay Round Agreement? The regression results allow an answer to that question - the estimated abnormal return is equal to $\beta X$, and the market value created and destroyed by the Uruguay Agreement is $\beta X$ times the initial market value of an industry. Using values from regressions (2) and (3) reported in Table 6, the Uruguay Round Agreement increased the market value of above-average technology-intensive industries by $\$ 6.874$ billion. The sample includes 30 such industries with an initial aggregate value of $\$ 1,100$ billion $(0.62 \%)$. It decreased the market value of below-average technology-intensive industries by $\$ 5.633$ billion, out of 172 such industries with an initial aggregate value of $\$ 1,755$ billion $(0.33 \%)$. The net value created is $\$ 1.241$ billion. Similarly, the Uruguay Round Agreement increased the market value of net exporting industries by $\$ 0.923$ billion, out of 49 such industries with an initial aggregate value of $\$ 972$ billion ( $0.09 \%)$. It reduced the market value of net importing industries by $\$ 1.765$ billion out of 87 such industries with an initial aggregate value of $\$ 1,244$ billion $(0.14 \%)$. The net value destruction is $\$ 0.834$ billion. The above numbers suggest that the net economic effect of the Uruguay Round Agreement is limited.

\section{CONCLUSIONS AND IMPLICATIONS}

This article uses the event study methodology to capture the effects of the Uruguay Round on U.S. business. It is unique in the sense that it uses a market assessment to identify the likely beneficiaries of the trade liberalization brought about by the Uruguay Round Agreement. While the agreement does not affect the overall market return, it does appear to cause an appreciation of cap- 
ital values in industries with above-average technology intensity and in net exporting industries, and to reduce capital values in industries with below-average technology intensity and in net importing industries.

These statistically significant results are consistent with the interpretation that investors believe the conclusion of the Uruguay Round of negotiations was a noteworthy event with offsetting effects. Investors expect industries with comparative advantage to be best able to take advantage of concessions offered by foreign countries in the Uruguay Round, while industries with comparative disadvantage will lose as a result of diminished import protection. In the case of technology-intensive U.S. industries, enhanced intellectual property protection increases their value, regardless of the location of their production.

The economic significance attached by investors to the event, however, is rather small -investors do not increase (decrease) the capital value of comparative advantage (disadvantage) industries by more than $1 \%$, and in most cases the change is less than $0.5 \%$. Thus, investors' assessment and economists' CGE model simulation results convergethe economic impact of the Uruguay Round Agreement is limited despite its political significance. Much multilateral political effort in implementing the Uruguay Round Agreement will be necessary for it to create more economic value.

\section{REFERENCES}

Baldwin, Robert E., "Determinants of the Commodity Structure of U.S. Trade," American Economic Review, 61:1, March 1971, 126-146.

The Political Economy of U.S. Import Policy, MIT Press, Cambridge, Mass., 1985.

Brander, James A., "Election Polls, Free Trade, and the Stock Market: Evidence from the Canadian General Election," Canadian Journal of Economics, 24:4, November 1991, 827-843.

Brown, Stephen J., and Jerold B. Warner, "Measuring Security Price Performance," Journal of Financial Economics, 8:3, September 1980, 205-258.

, "Using Daily Stock Returns: The Case of Event Studies," Journal of Financial Economics, 14:1, March 1985, 3-31.

Congressional Quarterly Almanac, 1994, Congressional Quarterly, Washington, D.C., 1994.
Deardorff, Alan V., "Testing Trade Theories and Predicting Trade Flows," in Handbook of International Economics, R. Jones and P. Kennen, eds., Elsevier, New York, 1984, 467-517.

"Economic Effects of Quota and Tariff Reductions," in The New GATT: Implications for the United States, S. Collins and B. Bosworth, eds., Brookings, Washington, D.C., 1994, 7-27.

Grossman, G. M., and J. A. Levinsohn, "Import Competition and the Stock Market Return to Capital," American Economic Review, 79:5, December 1989, $1,065-1,087$.

Harrison, Glenn, Thomas Rutherford, and David Tarr, "Quantifying the Uruguay Round," Economic Journal, 107:444, September 1997, 1,405-1,430.

Hartigan, James, Philip Perry, and Sreenivas Kamma, "The Value of Administered Protection: A Capital Market Approach," Review of Economics and Statistics, 68:4, November 1986, 610-617.

Ingersoll, Jonathan E. Jr., and Stephen A. Ross, "Waiting to Invest: Investment and Uncertainty," Journal of Business, 65:1, January 1992, 1-29.

Lenway, Stefanie, Randall Morck, and Bernard Yeung, "Rent Seeking, Protectionism and Innovation in the American Steel Industry," Economic Journal, 106:435, March 1996, 410-421.

Martin, Will, and Alan Winters, The Uruguay Round and the Developing Countries, Cambridge University Press, New York, 1996.

Maskus, Keith, and Denise Eby Konan, “Trade-Related Intellectual Property Rights: Issues and Exploratory Results," in Analytical and Negotiating Issues in the Global Trading System, A. Deardorff and R. Stern, eds., University of Michigan Press, Ann Arbor, 1994, 401-446.

Morck, Randall, Bernard Yeung, and Wayne Yu, "The Information Content of Stock Markets: Why Do Emerging Markets Have Synchronous Stock Price Movements?" University of Michigan Working Paper No. 44a, 1998.

Mussa, Michael, "Tariffs and the Distribution of Income: The Importance of Factor Specificity, Substitutability, and Intensity in the Short and Long Run," Journal of Political Economy, 82:6, December 1974, 1,191-1,204.

Preeg, Ernest, Traders in a Brave New World, University of Chicago Press, Chicago, 1995.

Schott, Jeffrey, The Uruguay Round: An Assessment, Institute for International Economics, Washington, D.C., 1994.

Thompson, Aileen, "The Anticipated Sectoral Adjustment to the Canada-United States Free Trade Agreement: An Event Study Analysis," Canadian Journal of Economics, 26:2, May 1993, 253-271.

"Trade Liberalization, Comparative Advantage, and Scale Economies: Stock Market Evidence from Canada," Journal of International Economics, 37:1-2, August 1994, 1-27.

White, Halbert, "A Heteroskedasticity-Consistent Covariance Matrix Estimator and a Direct Test for Heteroskedasticity," Econometrica, 48:4, May 1980, 817-838. 